\title{
Diagnostic leaf to evaluate the nutritional status of Jatropha
}

\author{
Carlos Hissao Kurihara ${ }^{*}$, Cesar José da Silva ${ }^{1}$ \\ http://dx.doi.org/10.1590/0034-737X201562060014
}

\begin{abstract}
The analytical determination of nutrient levels in recently mature leaves in order to diagnose nutritional status is based on the fact that leaves are metabolically active and more sensitive to variation in nutrients of the soil. In most of cases, there is a well known relation between foliar content and the development and yield of the plant. However, for a more accurate interpretation, it is essential to establish the index leaf. There are few published studies about Jatropha with contrasting results. In order to establish the index leaf, in adult plants, the macronutrient levels were evaluated in samples collected in experimental plots, in which doses of nitrogen and phosphorus were applied, in two parts of the floral branches (in the top and in the middle thirds); and in three positions of leaves of the floral branch (between the $1^{\text {st }}$ and $3^{\text {rd }}, 6^{\text {th }}$ and $8^{\text {th }}$, and $13^{\text {th }}$ and $15^{\text {th }}$ leaves below the inflorescence). The location of the leaf on the plant significantly affects nutrient contents. Nitrogen, phosphorus, potassium and sulfur tend to have higher concentration in young tissues. Calcium and magnesium showed higher levels in the basal leaves of floral branches. Samples collected in the top third of plants (between the $6^{\text {th }}$ and $15^{\text {th }}$ leaves of the floral branch) are more sensitive to variations of nitrogen and phosphorus fertilization. Therefore, we inchcate the $6^{\text {th }}$ to $15^{\text {th }}$ leaves of the top third of plants as index leaves to estimate nutritional status of Jatropha.
\end{abstract}

Key words: leaf analysis, index leaf, nitrogen, phosphorus.

\section{RESUMO}

\section{Folha diagnóstica para a avaliação do estado nutricional do pinhão-manso}

A determinação analítica dos teores de nutrientes em amostras de folhas recém-maduras, visando à diagnose do estado nutricional, é embasada no fato de este órgão ser metabolicamente ativo e mais sensível a variações na disponibilidade de nutrientes no solo, havendo, até certo ponto, relação direta com o desenvolvimento e a produção da planta. Contudo, para que a sua interpretação seja adequada, é preciso estabelecer a folha diagnóstica. Para o pinhão-manso, trabalhos publicados sobre este assunto têm mostrado resultados conflitantes. Assim, com o objetivo de se definir a folha diagnóstica em plantas adultas, avaliaram-se teores de macronutrientes em amostras coletadas em parcelas experimentais, nas quais se aplicaram doses de nitrogênio e de fósforo, em duas posições dos ramos florais (terço superior e terço médio da planta) e em três posições das folhas no ramo floral (entre a $1^{\mathrm{a}}$ e a $3^{\mathrm{a}}$, entre a $6^{\mathrm{a}}$ e a $8^{\mathrm{a}}$ e entre a $13^{\mathrm{a}}$ e a $15^{\mathrm{a}}$ folhas abaixo da inflorescência). A localização da folha na planta influencia significativamente os teores de nutrientes, sendo que $\mathrm{N}, \mathrm{P}, \mathrm{K}$ e S tendem a apresentar maior concentração nos tecidos mais novos e, $\mathrm{Ca}$ e $\mathrm{Mg}$, nas folhas basais do ramo floral, principalmente no terço médio. Constatou-se, também, que amostras coletadas em ramos do terço superior da planta, entre a sexta e a décima quinta folhas do ramo floral, apresentam maior sensibilidade às variações do fornecimento de $\mathrm{N}$ e $\mathrm{P}$ pela adubação, razão pela qual é indicado este padrão de amostragem como folha índice para fins de diagnose nutricional de pinhão-manso.

Palavras-chave: análise foliar, folha índice, nitrogênio, fósforo.

\footnotetext{
Submitted on 07/07/2014 and aproved on 07/14/2015

1 Embrapa Agropecuária Oeste, Dourados, Mato Grosso do Sul, Brazil. carlos.kurihara@embrapa.br; cesar.silva@embrapa.br

*Corresponding author: carlos.kurihara@embrapa.br
} 


\section{INTRODUCTION}

The diagnosis of the nutritional status of a crop can be done through the interpretation of the results of leaf analysis, using different methods, the most known being the sufficiency range and the diagnosis and recommendation integrated system (DRIS).

Regardless of the method adopted, it is essential to establish the type of leaf or its location in the plant, that is, the definition of the diagnostic leaf or index leaf. This standardization is important to avoid false diagnoses of deficiencies, excesses or nutritional imbalances, which can lead to unnecessary increases in production costs, due to the application of non-limiting nutrients to the development of the crop; or else, the decrease of productivity, due to the failure to detect nutritional deficiencies or supply of elements that were already in excess.

This principle of nutritional status assessment, despite its obviousness, in some situations may go unnoticed. For soybeans, for example, there is the indication of collecting samples of the third trefoil from the apex (Malavolta et al., 1997 and Embrapa Soja, 2002), as well as this trefoil accompanied by petioles (Battaglia et al., 1996 and Ribeiro et al., 1999), knowing that the sufficiency ranges used for the interpretation of foliar analysis were the same for both types of index leaf (Kurihara, 2004). However, based on the evaluation of leaf samples collected in commercial crops, Kurihara (2004) and Maeda et al. (2004) found higher levels of $\mathrm{N}, \mathrm{P}, \mathrm{Cu}, \mathrm{Fe}, \mathrm{Mn}$ and $\mathrm{Zn}$ and lower $\mathrm{K}$ in the leaf blade, compared to the third trefoil with petiole. According to these authors, the differentiated accumulation of nutrients in the leaf blade and petiole reinforces the need for setting reference values, specific to each type of index leaf sampled, which was done by Kurihara (2004) and later in the second approach, by Kurihara et al. (2013).

To establish the type of index leaf more suitable for the diagnosis of nutritional status, various methods have been used, including the relationship between the nutrient content of the leaf sample in evaluation and the contents of these nutrients in a representative sample of the whole plant (Siebeneichler et al., 2002 and Souza et al., 2011), or the amount of such nutrients accumulated in the aerial part (Souza et al., 2011), or the crop yield (Lavorenti et al. 1982; Silva et al, 2010). On the other hand, the index leaf has also been indicated from the simple comparison of average nutrient contents in leaf samples of plants of a commercial crop, in different positions in the branch (Lima et al., 2011a).

Studies already conducted with Jatropha crop have tended to show no significant differences in leaf nutrient content in the floral branches, compared with the vegetative branches (Lima et al., 2011a). Regarding the type of index leaf, the results are conflicting, which indicates that the most suitable leaves for diagnosis are those located on the second or third node of the secondary branch (Lima et al., 2011a), or in the middle portion of the the plant in the main or side branch, regardless of the position of the leaf in the branch (Silva et al., 2010).

This study was conducted in order to establish the type of index leaf most appropriate for the diagnosis of the nutritional status of adult plants of Jatropha, from tests conducted in branches of the middle and top third of the plant canopy and three positions of leaves in floral branches.

\section{MATERIALAND METHODS}

The two experiments were conducted in Dourados, MS, on Oxisol, medium texture. Before the experiments, collection of soil samples was carried out at two depths for determination of chemical and physical properties (Table 1), according to Silva et al. (1999).

We adopted the experimental randomized block design, distributed in divided plots with three replications. In the plots, four treatments of fertilization at planting were evaluated and in the subplots, five maintenance fertilization treatments. The subplot consisted of four useful plants, spaced 4 x 2 m (density of 1,250 plants ha ${ }^{-1}$ ).

In one of the experiments, $0,30,60$ and $90 \mathrm{~g} \mathrm{plant}^{-1}$ of $\mathrm{N}$ (equivalent to $0,37.5,75$ and $112.5 \mathrm{~kg} \mathrm{ha}^{-1} \mathrm{~N}$ ) were applied in the plots at the planting of seedlings (October 2009), and in the holes an amount of $\mathrm{N}$ was applied, equivalent to $33 \%$ of that established for each treatment, in addition to the basic fertilization with $125 ; 25 ; 2.0$; 2.0 ; and $4.0 \mathrm{~kg} \mathrm{ha}^{-1}$ of $\mathrm{P}_{2} \mathrm{O}_{5}, \mathrm{~K}_{2} \mathrm{O}, \mathrm{B}, \mathrm{Cu}$ and $\mathrm{Zn}$, respectively. At 104 days after planting, the remaining amount of nitrogen fertilization treatments was applied, associated with more $25 \mathrm{~kg} \mathrm{ha}^{-1}$ of $\mathrm{K}_{2} \mathrm{O}$. In the subplots, at 13 and 25 months after planting, 0, 30, 60, 90 and 120 g plant ${ }^{-1} \mathbf{N}\left(0,37.5,75,112.5\right.$ and $\left.150 \mathrm{~kg} \mathrm{ha}^{-1} \mathbf{N}\right)$ were applied as maintenance fertilizer. The distribution of nitrogen maintenance fertilizer was also divided in two times, being applied in each one, half the amount of $\mathrm{N}$ established for each treatment, and $37.5 \mathrm{~kg} \mathrm{ha}^{-1}$ of $\mathrm{P}_{2} \mathrm{O}_{5}$ and $25 \mathrm{~kg} \mathrm{ha}^{-1} \mathrm{~K}_{2} \mathrm{O}$. The second portion of maintenance fertilizer was applied at 49 and 28 days after the first, in 2010 and 2011, respectively.

In the second experiment, doses of $0,40,80$ and 120 $\mathrm{g}_{\text {hole }}{ }^{-1} \mathrm{P}_{2} \mathrm{O}_{5}$ (equivalent to $0,50,100$ and $150 \mathrm{~kg} \mathrm{ha}^{-1}$ of $\mathrm{P}_{2} \mathrm{O}_{5}$ ) were applied in the plots, and 0,30, 60, 90 and 120 $\mathrm{g}_{\text {plant }}^{-1}$ of $\mathrm{P}_{2} \mathrm{O}_{5}\left(0,37.5,75,112.5\right.$ and $150 \mathrm{~kg} \mathrm{ha}^{-1}$ of $\mathrm{P}_{2} \mathrm{O}_{5}$ ) in the subplots, at 13 and 25 months after planting. 
The basic fertilization in the planting of seedlings consisted on the application of $37.5 ; 25 ; 2.0 ; 2.0$; and 4.0 $\mathrm{kg} \mathrm{ha}^{-1}$ of $\mathrm{N}, \mathrm{K}_{2} \mathrm{O}, \mathrm{B}, \mathrm{Cu}$ and $\mathrm{Zn}$, respectively. Topdressing was also applied with 37.5 and $25 \mathrm{~kg} \mathrm{ha}^{-1}$ of $\mathrm{N}$ and $\mathrm{K}_{2} \mathrm{O}$, respectively, in the same periods mentioned above.

In both experiments, we used ammonium nitrate, triple superphosphate, potassium chloride, borax, copper sulphate and zinc sulphate as sources of $\mathrm{N}, \mathrm{P}_{2} \mathrm{O}_{5}, \mathrm{~K}_{2} \mathrm{O}$, $\mathrm{B}, \mathrm{Cu}$ and $\mathrm{Zn}$, respectively.

At 29 months after planting the seedlings, leaf samples with petiole were collected in the three useful plants of the plots, in two locations of the floral branches (top third and middle third of the plant) and in three positions of the leaves in the floral branch (between $1^{\text {st }}$ and $3^{\text {rd }}$, between the $6^{\text {th }}$ and the $8^{\text {th }}$ and between the $13^{\text {th }}$ and the $15^{\text {th }}$ leaves below the inflorescence). Each sample consisted of 30 leaves, collected from floral branches located throughout the length of the canopy. These leaf samples were subjected to sequenced cleaning with water, acid solution $(\mathrm{HCl} 0.1$ mol $\mathrm{L}^{-1}$ ) and distilled water. After drying in a forced air circulation oven at $65^{\circ} \mathrm{C}$ for $72 \mathrm{~h}$, they were ground in a Wiley mill (0.85 mm sieve) for subsequent chemical analysis of samples according to Malavolta et al. (1997). $\mathrm{N}$ was extracted by sulfuric acid digestion and determined by the semimicro-Kjeldahl method; $\mathrm{P}, \mathrm{K}, \mathrm{Ca}, \mathrm{Mg}$ and $\mathrm{S}$, by nitric-perchloric digestion and determined by molecular absorption spectrometry $(\mathrm{P})$, emission flame photometry $(\mathrm{K})$, atomic absorption spectrophotometry $(\mathrm{Ca}$ and $\mathrm{Mg}$ ) and barium sulfate turbidimetry $(\mathrm{S})$.

The data were submitted to analysis of variance through the SAEG software, v. 9.1 - 2007, given that the six types of index leaves constituted a factorial with the five doses of $\mathrm{N}$ or $\mathrm{P}$ evaluated in the subplots. The averages of macronutrient contents determined in the six types of index leaves were compared by Tukey test at $5 \%$ probability. The effects of nitrogen and phosphate fertilizations on foliar contents of $\mathrm{N}$ and $\mathrm{P}$, respectively, were determined through adjustment of regression models. Among the regression models tested (linear, quadratic, square root and exponential), the one with the highest coefficient of determination was defined for each set of variables, whose parameter estimators of the equation were significant to at least $5 \%$ probability.

\section{RESULTS AND DISCUSSION}

To assess the effect of the type of index leaf, collected in sampling of Jatropha leaves, on the macronutrient content, these effects were compared independently of the doses of $\mathrm{N}$ or $\mathrm{P}$, applied at planting or top dressing ( Tables 2 and 3).

In both experiments, it was observed that the foliar contents of N, P, K and S tended to be significantly higher in young tissues (between the $1^{\text {st }}$ and $3^{\text {rd }}$ leaves below the inflorescence), regardless of the position of the floral branch (Tables 2 and 3). The contents of these nutrients in samples collected between the $6^{\text {th }}$ and the $8^{\text {th }}$ leaves below the inflorescence, tended not to differ from those determined in samples collected between the $13^{\text {th }}$ and the $15^{\text {th }}$ leaves; in general, in both positions in the floral branch, the contents were significantly lower than those observed in samples collected at the distal end of the branch. On the other hand, it was found that, in general, the $\mathrm{Ca}$ and $\mathrm{Mg}$ contents were significantly higher in leaves collected between the $13^{\text {th }}$ and $15^{\text {th }}$ positions of the floral branch, located in the middle third of the plant, compared with the given contents in leaves collected in the top third position and in the apex. In the branches located in the top third of the plant, this concentration gradient of $\mathrm{Ca}$ and $\mathrm{Mg}$ also occurred, but to a lesser extent (Tables 2 and 3). This reflects the accumulation of nutrients in the tissues, depending on their mobility in the phloem. The highest contents of mobile nutrients $(\mathrm{N}$, $\mathrm{P}, \mathrm{K}$ and $\mathrm{S}$ ) in the younger leaves are due to the translocation of these nutrients from older tissues. On the other hand, $\mathrm{Ca}$ accumulation, over time, results in higher contents observed in older leaves (Marschner, 2002) due to its non redistribution in the phloem, associated with its role in the formation of cellular structures. $\mathrm{Mg}$, in turn, despite its high mobility in the phloem, may have accumulated in the older leaves, as it also occurs in other plant species (Malavolta, 2006),

Table 1: Chemical $^{1}$ and physical characterization of the soil in the experimental area

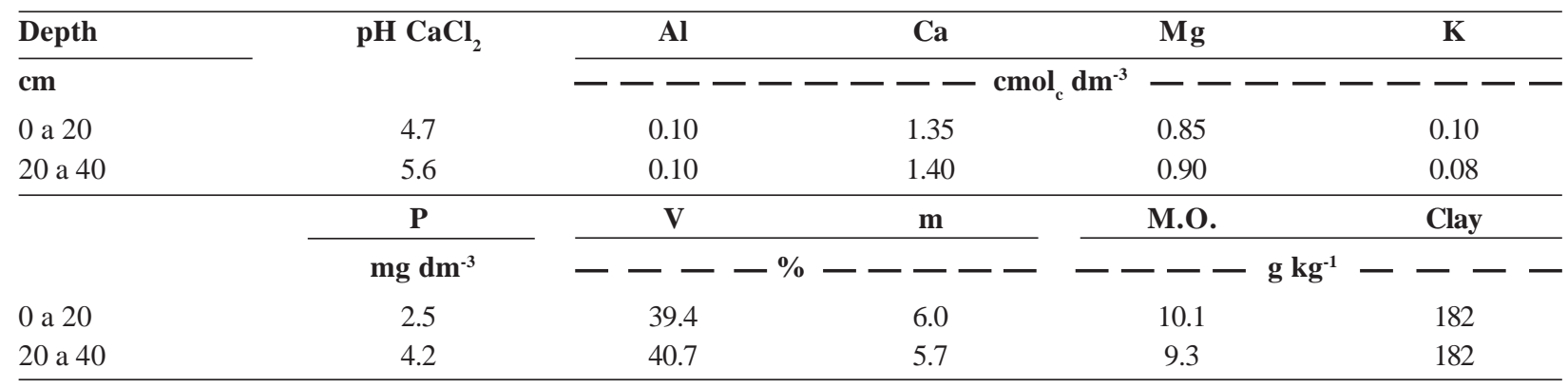

${ }^{1} \mathrm{P}$ and $\mathrm{K}$ extracted by Mehlich-1. 
since the demand for this nutrient is not so high in newer structures (Lima et al., 2011a). These results partially agree with those obtained by Lima et al. (2011b) in samples collected in commercial crops of Jatropha in the state of Pernambuco, with 3.5 years of age; they found an intense redistribution of $\mathrm{P}, \mathrm{K}, \mathrm{Cu}$ and $\mathrm{Zn}$ from older leaves to younger tissues; for the nutrients $\mathrm{N}, \mathrm{Ca}$, $\mathrm{Mg}, \mathrm{Fe}$ and $\mathrm{Mn}$, this was of little degree.

Given the existence of significant differences in macronutrient content, due to the leaf location on the plant, it is important to establish a pattern of collecting leaf samples in order to obtain the proper interpretation of the nutritional status of the crop.

In this work, we chose for the adjustment of the regression model between the macronutrient contents in the different index leaves and the doses of $\mathrm{N}$ and $\mathrm{P}$ applied. There was no significant effect of base fertilization on leaf contents in samples collected at 29 months after transplantation, except for calcium, in the test with doses of phosphorus. There was also no significant differences for effect of the interaction between the top dressing, at 13 and 23 months after transplantation, and the doses of $\mathrm{N}$ and $\mathrm{P}$ applied at planting. For this reason, the adjustment of regression models was performed between foliar contents of $\mathrm{N}$ and $\mathrm{P}$ in different index leaves, doses of $\mathrm{N}$ applied in top dressing and the sum of doses of $\mathrm{P}$ applied at planting and in the two top dressings, respectively, considering that the contents of the latter may also reflect the residual effect of the previously supplied nutrient.

When performing the regression analysis there was the adjustment of the linear and quadratic models (Figures 1 and 2). In both experiments, the highest coefficients of determination were generally obtained by the sampling performed in the top third of the plant, especially when the index leaf was collected between the sixth and the eighth or between the thirteenth and fifteenth leaves from the inflorescence. Leaf samples collected in the middle third of the plant also showed equivalence of the coefficient of determination values for collections made

Table 2: Macronutrient contents in leaf samples of Jatropha, collected at 29 months after transplanting of seedlings, in two positions of floral braches of the plant (top and midlle thirds) and in three positions in the floral branch ${ }^{1}$, in nitrogen ${ }^{2}$ fertilization experiment

\begin{tabular}{|c|c|c|c|c|c|c|c|}
\hline \multirow{2}{*}{$\begin{array}{l}\text { Position } \\
\text { of the branch }\end{array}$} & \multirow{2}{*}{$\begin{array}{c}\text { Position } \\
\text { of leaf }\end{array}$} & $\mathbf{N}$ & $\mathbf{P}$ & $\mathbf{K}$ & $\mathrm{Ca}$ & $\mathrm{Mg}$ & $\mathbf{S}$ \\
\hline & & \multicolumn{6}{|c|}{$\mathrm{g} \mathrm{kg}^{-1}$} \\
\hline \multirow{3}{*}{ Top Third } & $1^{\mathrm{a}}$ a $3^{\mathrm{a}}$ & $29.7 \mathrm{a}$ & $3.1 \mathrm{a}$ & $23.9 \mathrm{ab}$ & $9.2 \mathrm{~cd}$ & $9.4 \mathrm{bc}$ & $1.4 \mathrm{a}$ \\
\hline & $6^{\mathrm{a}}$ a $8^{\mathrm{a}}$ & $26.2 \mathrm{~b}$ & $2.6 \mathrm{~b}$ & $22.3 \mathrm{bc}$ & $10.4 \mathrm{bc}$ & $9.9 \mathrm{bc}$ & $1.1 \mathrm{c}$ \\
\hline & $13^{\mathrm{a}}$ a $15^{\mathrm{a}}$ & $24.8 \mathrm{~b}$ & $2.5 \mathrm{~b}$ & $21.9 \mathrm{c}$ & $10.9 \mathrm{~b}$ & $9.6 \mathrm{bc}$ & $1.1 \mathrm{c}$ \\
\hline \multirow{3}{*}{ Middle Third } & $1^{\mathrm{a}}$ a $3^{\mathrm{a}}$ & $29.4 \mathrm{a}$ & $3.1 \mathrm{a}$ & $24.8 \mathrm{a}$ & $9.1 \mathrm{~d}$ & $9.1 \mathrm{c}$ & $1.3 \mathrm{~b}$ \\
\hline & $6^{\mathrm{a}}$ a $8^{\mathrm{a}}$ & $25.1 \mathrm{~b}$ & $2.4 \mathrm{~b}$ & $22.0 \mathrm{bc}$ & $11.4 \mathrm{~b}$ & $10.3 \mathrm{ab}$ & $1.1 \mathrm{c}$ \\
\hline & $13^{\mathrm{a}}$ a $15^{\mathrm{a}}$ & $24.7 \mathrm{~b}$ & $2.4 \mathrm{~b}$ & $21.6 \mathrm{c}$ & $13.3 \mathrm{a}$ & $11.3 \mathrm{a}$ & $1.1 \mathrm{c}$ \\
\hline Means & & 26.7 & 2.7 & 22.8 & 10.7 & 9.9 & 1.2 \\
\hline C. V. $(\%)$ & & 12.1 & 19.1 & 16.4 & 21.7 & 19.7 & 18.8 \\
\hline
\end{tabular}

${ }^{1}$ It refers to the leaf position on floral branch, counted from the inflorescence. For each nutrient, means followed by the same lower case letter do not differ significantly by Tukey test at $5 \%$ probability. ${ }^{2}$ Mean values of four doses of nitrogen $\left(0,37.5,75\right.$ and $112.5 \mathrm{~kg}$ ha $\left.{ }^{-1} \mathrm{~N}\right)$ applied in the planting of seedlings in October 2008, and five doses $\left(0,37.5,75 ; 112.5\right.$ and $\left.150 \mathrm{~kg} \mathrm{ha}^{-1} \mathrm{~N}\right)$ applied in the maintenance, after 13 and 23 months.

Table 3: Macronutrient contents in samples of Jatropha leaves, collected at 29 months after transplantation, at two positions of floral branches in the plant (top and middle thirds) and three positions in the floral branch, in experiment of phosphorus fertilization ${ }^{2}$

\begin{tabular}{|c|c|c|c|c|c|c|c|}
\hline \multirow{2}{*}{$\begin{array}{l}\text { Branch } \\
\text { Position }\end{array}$} & \multirow{2}{*}{$\begin{array}{c}\text { Leaf } \\
\text { Position }\end{array}$} & $\mathbf{N}$ & $\mathbf{P}$ & $\mathbf{K}$ & $\mathbf{C a}$ & Mg & $\mathbf{S}$ \\
\hline & & \multicolumn{6}{|c|}{$\mathrm{g} \mathrm{kg}^{-1}$} \\
\hline \multirow{3}{*}{ Top Third } & $1^{\mathrm{a}}$ a $3^{\mathrm{a}}$ & $30.6 \mathrm{a}$ & $2.7 \mathrm{a}$ & $22.5 \mathrm{a}$ & $8.7 \mathrm{~cd}$ & $9.4 \mathrm{bc}$ & $1.4 \mathrm{a}$ \\
\hline & $6^{\mathrm{a}}$ a $8^{\mathrm{a}}$ & $26.7 \mathrm{~b}$ & $2.4 \mathrm{~b}$ & $20.7 \mathrm{~b}$ & $8.8 \mathrm{~cd}$ & $9.2 \mathrm{c}$ & $1.2 \mathrm{bc}$ \\
\hline & $13^{\mathrm{a}}$ a $15^{\mathrm{a}}$ & $24.2 \mathrm{c}$ & $2.1 \mathrm{c}$ & $18.2 \mathrm{c}$ & $10.6 \mathrm{~b}$ & $10.3 \mathrm{~b}$ & $1.1 \mathrm{~cd}$ \\
\hline \multirow{3}{*}{ Middle Third } & $1^{\mathrm{a}}$ a $3^{\mathrm{a}}$ & $28.4 \mathrm{~b}$ & $2.7 \mathrm{a}$ & $23.0 \mathrm{a}$ & $8.2 \mathrm{~d}$ & $8.6 \mathrm{c}$ & $1.3 \mathrm{ab}$ \\
\hline & $6^{\mathrm{a}}$ a $8^{\mathrm{a}}$ & $24.0 \mathrm{c}$ & $2.2 \mathrm{c}$ & $19.9 \mathrm{bc}$ & $9.6 \mathrm{bc}$ & $9.5 \mathrm{bc}$ & $1.0 \mathrm{~d}$ \\
\hline & $13^{\mathrm{a}}$ a $15^{\mathrm{a}}$ & $22.9 \mathrm{c}$ & $1.9 \mathrm{~d}$ & $18.5 \mathrm{c}$ & $14.1 \mathrm{a}$ & $12.6 \mathrm{a}$ & $1.1 \mathrm{~cd}$ \\
\hline Means & & 26.1 & 2.3 & 20.5 & 10.0 & 9.9 & 1.2 \\
\hline C. V. $(\%)$ & & 14.4 & 14.1 & 16.2 & 23.9 & 21.3 & 19.3 \\
\hline
\end{tabular}

${ }^{1}$ It refers to the leaf position on floral branch, counted from the inflorescence. For each nutrient, means followed by the same lower case letter do not differ significantly by Tukey test at $5 \%$ probability. ${ }^{2}$ Mean values of four levels of phosphorus $\left(0,50,100\right.$ and $150 \mathrm{~kg}^{-1}$ of $\left.\mathrm{P}_{2} \mathrm{O}_{5}\right)$ applied in the planting of seedlings, in November 2009 , and five doses $\left(0,37.5,75,112.5\right.$ and $150 \mathrm{~kg} \mathrm{ha}^{-1}$ of $\left.\mathrm{P}_{2} \mathrm{O}_{5}\right)$ on maintenance, after 13 and 23 months.

Rev. Ceres, Viçosa, v. 62, n.6, p. 607-613, nov-dez, 2015 
in the two more basal positions in the floral branch; however, they proved to be generally lower than the values obtained in the sampling from floral branches located in the top third; and, in both samplings from the middle third and the top third of the plant, it was observed that the sampling collected more closely to the inflorescences tended to be associated with considerably smaller adjustments between the variables.

These results indicate that the samples collected in the top third of the canopy, between the sixth and fifteenth leaves of the floral branch, are more sensitive to changes in nutrient availability in the soil, resulting from the supply in the planting $(\mathrm{P})$ and top dressing $(\mathrm{N}$ and $\mathrm{P}$ ) fertilizations. The greater sensitivity of the index leaf collected in the top third of the canopy may be related to the fact that in perennial plants, much of the metabolically active leaves
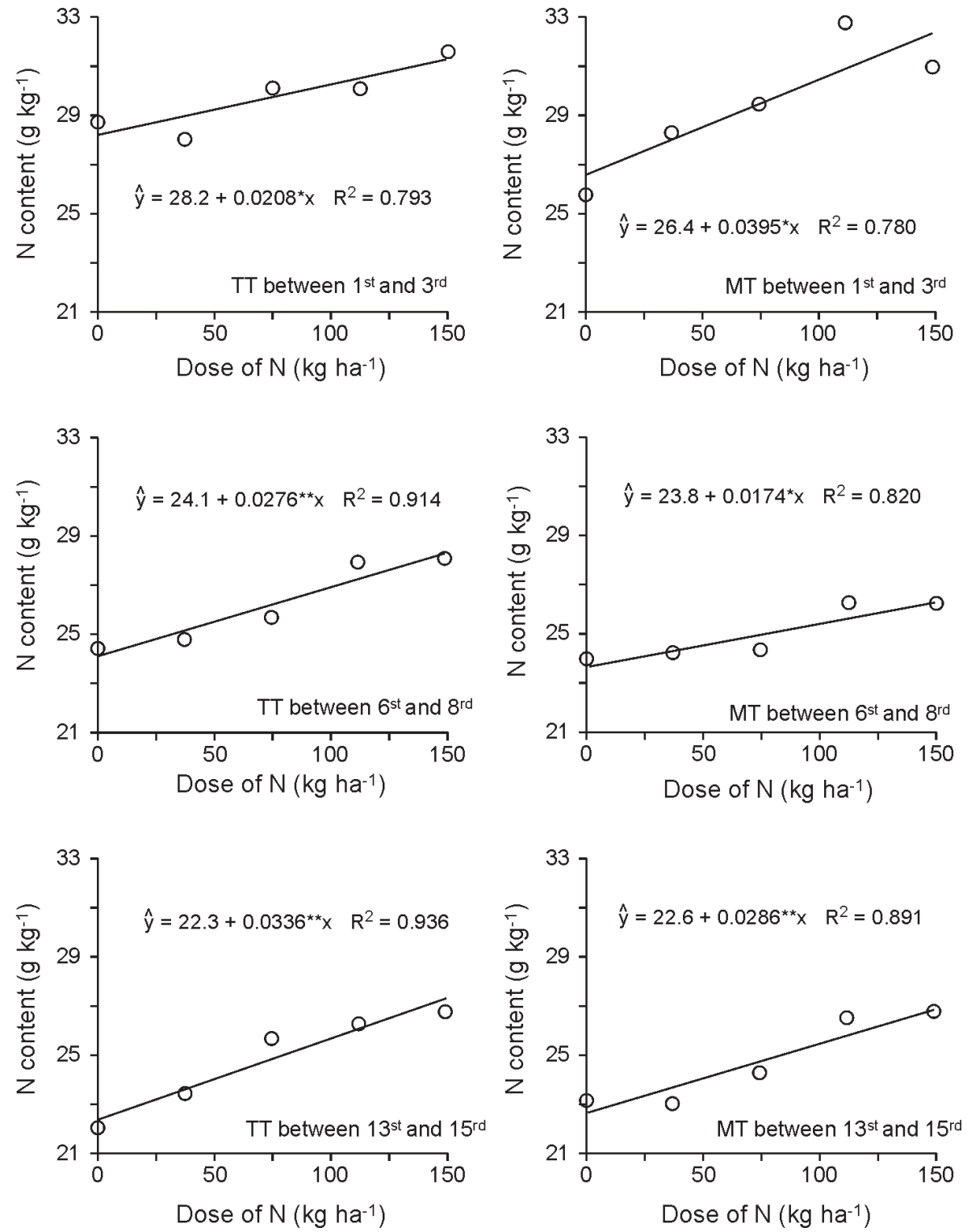

Figure 1: $\mathrm{N}$ fertilization effect on top dressing in nitrogen content, determined in samples of Jatropha leaves collected at 29 months after transplantation, at two positions of floral branches in the plant (TT = top third and MT $=$ middle third $)$ and in three positions in the floral branch (between the $1^{\text {st }}$ and $3^{\text {rd }}$, between the $6^{\text {th }}$ and $8^{\text {th }}$ and between the $13^{\text {th }}$ and the $15^{\text {th }}$ leaves below the inflorescence). 
distal part of the branch, due to lower development of the tree canopy and, therefore, to less competition for light. According to Luyssaert et al. (2002), exposure to light may affect the leaf contents, due to differences in the translocation of nutrients and carbohydrates among the leaves and the transpiration rate. Therefore, the pattern of spatial distribution between the leaves more exposed to light and shaded leaves may result in differences in the accumulation of nutrients in different parts of the plant canopy. According to these authors, contrasting patterns of nutrient accumulation in perennial plants have been reported in the literature, which can be explained by the fact that there are internal adjustment mechanisms to maintain favorable growth conditions in metabolically active leaves.
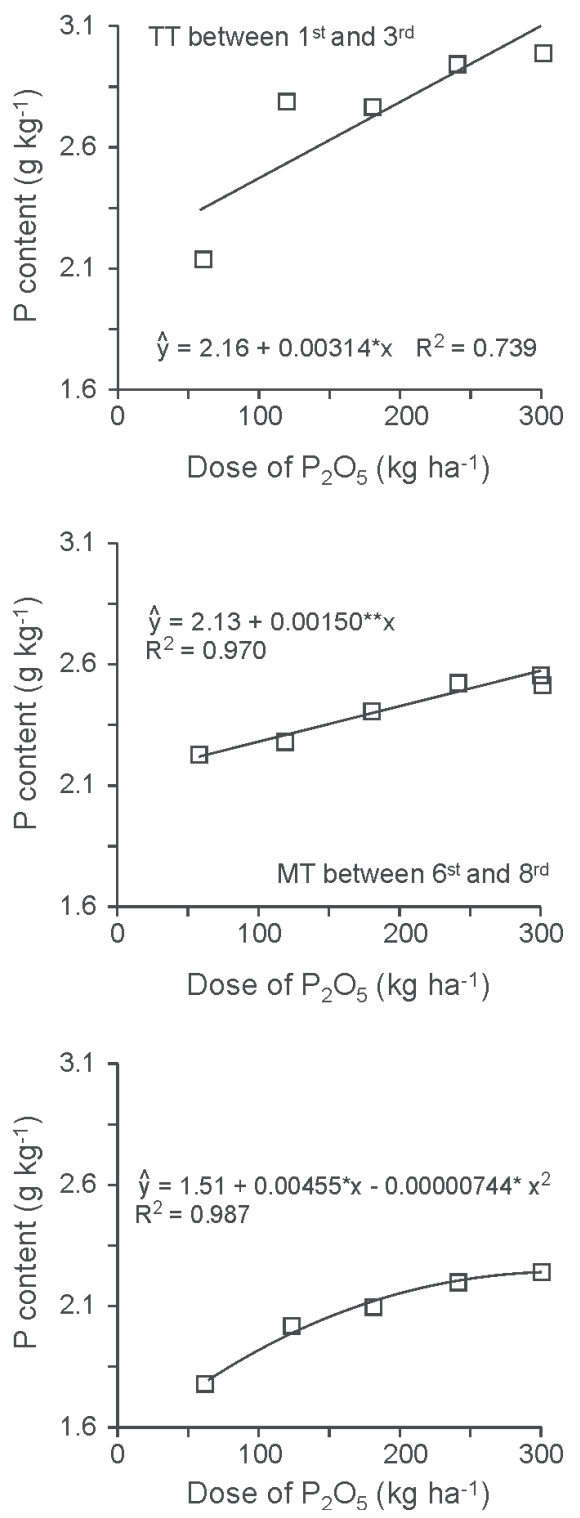

The sampling pattern obtained also contrasts with that suggested by Lima et al. (2011a), according to which, in plants with 3.5 years of age, the leaves located on the second or third node of the secondary branch are the most suitable for foliar diagnosis of Jatropha. However, the discrepancy in defining the index leaf may be in the fact that these authors were based simply on the comparison of average nutrient contents in leaf samples collected in plants of a commercial crop in different positions in the branch; therefore they suggested sampling in the second or third node of the secondary branch, because these leaves present intermediate values in nutrient contents, compared to those located in the distal and basal parts of the branches.
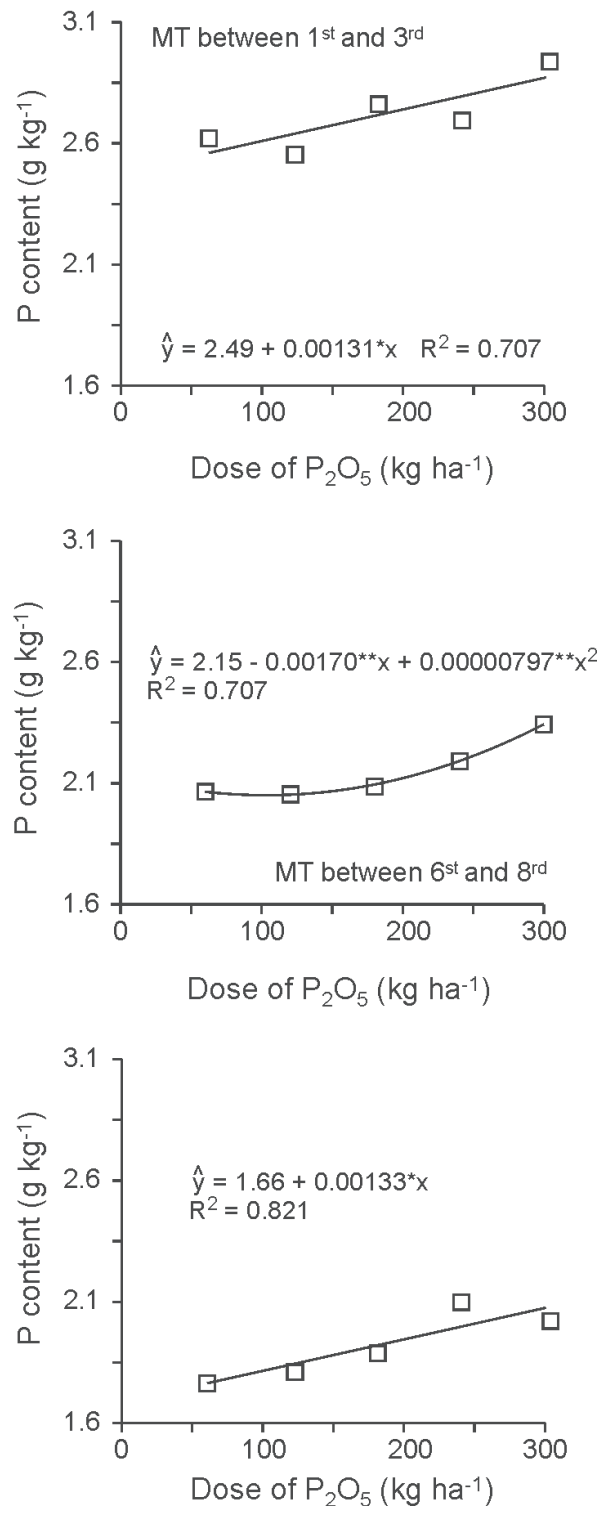

Figure 2: $\mathrm{P}$ fertilization effect on phosphorus content determined in samples of Jatropha leaves collected at 29 months after transplantation, at two positions of floral branches in the plant (TT $=$ top third and MT $=$ middle third $)$ and three positions on floral branch (between the $1^{\text {st }}$ and $3^{\text {rd }}$, between the $6^{\text {th }}$ and $8^{\text {th }}$ and between the $13^{\text {th }}$ and $15^{\text {th }}$ leaves below the inflorescence). 


\section{CONCLUSIONS}

There are significant differences in macronutrient content, depending on the leaf position in the branches, regardless of the position of the floral branch on the Jatropha plant.

For nutritional diagnosis of Jatropha, it is recommended to collect leaf samples in the top third of the branches of the plant.

As index leaf, it is recommended to take one of those located between the sixth and fifteenth leaves of the floral branches because they are more sensitive to changes in nutrient availability in the soil.

\section{ACKNOWLEGEMENT}

The authors thank Embrapa, the MCT / FINEP and PETROBRAS for the financial support to this research.

\section{REFERENCIAS}

Bataglia OC, Dechen AR \& Santos WR dos (1996) Princípios da diagnose foliar. In: Alvarez V VH, Fontes LEF \& Fontes MPF (Eds.) O solo nos grandes domínios morfoclimáticos do Brasil e o desenvolvimento sustentado. Viçosa, UFV. p.647-660.

Embrapa Soja (2002) Tecnologias de produção de soja - Paraná 2003. Embrapa Soja, Londrina. 195p. (Sistemas de produção, 2).

Kurihara CH (2004) Demanda de nutrientes pela soja e diagnose de seu estado nutricional. Tese de Doutorado. Universidade Federal de Viçosa, Viçosa. 100p.

Kurihara CH, Alvarez Venegas VH, Neves JCL, Novais RF de \& Staut LA (2013) Faixas de suficiência para teores de nutrientes em algodão e em soja, definidas em função de índices DRIS. Revista Ceres, 60:412419.

Lavorenti A, Gallo PB, Sawazaki E \& Hiroce R (1982) Amostragem de folhas de milho para fins de diagnose de nutrição nitrogenada. Bragantia, 41:219-224.

Lima RLS de, Severino LS, Cazetta JO, Azevedo CAV de, Sofiatti V \& Arriel NHC (2011a) Posição da folha e estádio fenológico do ramo para análise foliar do pinhão-manso. Revista Brasileira de Engenharia Agrícola e Ambiental, 15:1068-1072.

Lima RLS de, Severino LS, Cazetta JO, Azevedo CAV de, Sofiatti V \& Arriel NHC (2011b) Redistribuição de nutrientes em folhas de pinhãomanso entre estádios fenológicos. Revista Brasileira de Engenharia Agrícola e Ambiental, 15:1175-1179.

Luyssaert S, Raitio H, Vervacke P, Mertens J \& Lust N (2002) Sampling procedure for the foliar analysis of deciduous trees. Journal of Environmental Monitoring, 4:858-864.

Maeda S, Lima Filho OF de \& Fabrício AC (2004) Análise de amostras de folha de soja: com ou sem pecíolo? Dourados, Embrapa Agropecuária Oeste. 5p. (Comunicado Técnico, 96).

Malavolta E (2006) Manual de nutrição mineral de plantas. São Paulo, Livroceres. 638p

Malavolta E, Vitti GC \& Oliveira SA de (1997) Princípios, métodos e técnicas de avaliação do estado nutricional. In: Malavolta E, Vitti GC \& Oliveira SA de (Eds.) Avaliação do estado nutricional da plantas: princípios e aplicações. $2^{\mathrm{a}}$ ed. Piracicaba, Potafos. p.115-230.

Marschner H (2002) Mineral nutrition of higher plants. London, Academic. 889p.
Ribeiro AC, Guimarães PTG \& Alvarez VVH (1999) Recomendações para o uso de corretivos e fertilizantes em Minas Gerais: $5^{\mathrm{a}}$ aproximação. Viçosa, Comissão de Fertilidade do Solo do Estado de Minas Gerais. 359p.

Siebeneichler SC, Monnerat PH, Carvalho AJC de \& Silva JA da (2002) Composição mineral da folha em abacaxizeiro: efeito da parte da folha analisada. Revista Brasileira de Fruticultura, 24:194-198.

Silva FC da, Eira PA da, Raij B Van, Silva CA, Abreu CA de, Gianello C, Pérez DV, Quaggio JA, Tedesco MJ, Abreu MF de \& Barreto W de O (1999) Análises químicas para avaliação da fertilidade do solo. In: Silva FC da (Org.) Manual de análises químicas de solos, plantas e fertilizantes. Brasília, Embrapa Comunicação para Transferência de Tecnologia. p.75-169.

Silva E de B, Souza PT de, Santos SR \& Tanure LPP (2010) Diagnose foliar do pinhão manso: definição da folha no tipo e posição do ramo. In: XXIX Reunião Brasileira de Fertilidade do Solo e Nutrição de Plantas; XIII Reunião Brasileira sobre Micorrizas; XI Simpósio Brasileiro de Microbiologia do Solo; VII Reunião Brasileira de Biologia do Solo, Viçosa. Anais, SBCS. CD-ROM.

Souza HA de, Hernandes A, Romualdo LM, Rozane DE, Natale W \& Barbosa JC (2011) Folha diagnóstica para avaliação do estado nutricional do feijoeiro. Revista Brasileira de Engenharia Agrícola e Ambiental, 15:1243-1250. 